International Journal of

Environmental Research and

Public Health

ISSN 1660-4601

www.mdpi.com/journal/ijerph

Article

\title{
The Influence of Changes in Lifestyle and Mercury Exposure in Riverine Populations of the Madeira River (Amazon Basin) near a Hydroelectric Project
}

\author{
Sandra S. Hacon ${ }^{1, \dagger} *$, José G. Dórea ${ }^{2, \dagger}$, Márlon de F. Fonseca ${ }^{3, \dagger}$, Beatriz A. Oliveira ${ }^{1, \dagger}$, \\ Dennys S. Mourão ${ }^{1, \dagger}$, Claudia M. V. Ruiz ${ }^{4, \dagger}$, Rodrigo A. Gonçalves ${ }^{4, \dagger}$, Carolina F. Mariani ${ }^{5, \dagger}$ \\ and Wanderley R. Bastos ${ }^{6, \dagger}$
}

1 Escola Nacional de Saúde Público Sergio Arouca-Fundação Oswaldo Cruz, Rua Leopoldo Bulhões, 1480 Manguinhos, Rio de Janeiro, 21041-210, Brazil; E-Mails: beatrizenf@gmail.com (B.A.O.); dennys@ensp.fiocruz.br (D.S.M.)

2 Faculdade de Ciências da Saúde-Universidade de Brasília, C.P. 04322, Campus-Asa Norte,

Brasília, Distrito Federal, 70919-970, Brazil; E-Mail: jg.dorea@gmail.com

3 Instituto Fernandes Figueira-Fundação Oswaldo Cruz, Av. Rui Barbosa, 716 Flamengo,

Rio de Janeiro, 22250-020, Brazil; E-Mail: marlon@iff.fiocruz.br

4 Laboratório de Química da Pontifícia, Universidade Católica do Rio de Janeiro, R. Marquês de São Vicente, 225. Gávea, Rio de Janeiro, 22451-900, Brazil;

E-Mails: claudveg@yahoo.com (C.M.V.R.); rodrigoagoncalves@gmail.com (R.A.G.)

5 Santo Antônio Energia, Rua Tabajara, 824 - Olaria, Porto Velho, Rondônia, 76801-316, Brazil;

E-Mail: carolinamariani@ santoantonioenergia.com.br

6 Laboratório de Biogeoquímica Ambiental Wolfgang C. Pfeiffer, Universidade Federal de Rondônia, Porto Velho, RO, 76801-974, Brazil; E-Mail: wanderbastos@yahoo.com.br

$\dagger$ These authors contributed equally to this work.

* Author to whom correspondence should be addressed; E-Mail: sandrahacon@ gmail.com; Tel.: +55-21-2598-2655; Fax: +55-21-2598-2610.

Received: 13 December 2013; in revised form: 28 January 2014 / Accepted: 30 January 2014 / Published: 26 February 2014

Abstract: In the Amazon Basin, naturally occurring methylmercury bioaccumulates in
fish, which is a key source of protein consumed by riverine populations. The hydroelectric
power-plant project at Santo Antônio Falls allows us to compare the $\mathrm{Hg}$ exposure of
riverine populations sparsely distributed on both sides of the Madeira river before the area 
is to be flooded. From 2009 to 2011, we concluded a population survey of the area ( $\mathrm{N}=2,008$; representing circa $80 \%$ of community residents) that estimated fish consumption and mercury exposure of riverine populations with different degrees of lifestyle related to fish consumption. Fish samples from the Madeira river $(\mathrm{N}=1,615)$ and 110 species were analyzed for $\mathrm{Hg}$. Hair-Hg was significantly lower $(p<0.001)$ in less isolated communities near to the capital of Porto Velho (median $2.32 \mathrm{ppm}$ ) than in subsistence communities in the Cuniã Lake, $180 \mathrm{~km}$ from Porto Velho city (median $6.3 \mathrm{ppm}$ ). Fish $\mathrm{Hg}$ concentrations ranged from 0.01 to $6.06 \mu \mathrm{g} / \mathrm{g}$, depending on fish size and feeding behavior. Currently available fish in the Madeira river show a wide variability in $\mathrm{Hg}$ concentrations. Despite cultural similarities, riparians showed hair-Hg distribution patterns that reflect changes in fish-eating habits driven by subsistence characteristics.

Keywords: mercury in hair; fish intake; riverine communities; Amazon basin

\section{Introduction}

Methylmercury ( $\mathrm{MeHg}$ ) is a known neurotoxicant that accumulates in the food chain posing a significant risk to fish consumers, mainly women of childbearing age and young children. In the Amazon, naturally occurring $\mathrm{MeHg}$ bioaccumulates in fish, which is a key source of protein and essential nutrients in a cassava-based diet [1]. The habitual high fish intake of traditional riverine communities in the Amazon Basin represents a unique scenario for studying human exposure to mercury $(\mathrm{Hg})$, its interaction with endemic diseases, and the metabolism of toxic substances [2].

Fish consumption is high across all Amazonian populations, resulting in a relative increase in hair-Hg concentrations [3]. Dependence on fish consumption has showed to be a function of the traditional lifestyle associated with the isolation of Amazonian communities. Increase in hair- $\mathrm{Hg}$ concentrations as a function of distance to urban center centers was observed for subsistence villagers of Rio Negro [4]. Indeed, in the neighboring Bolivian Amazon, fish consumption tends to be higher among the more isolated and impoverished inhabitants [5].

The traditional lifestyle of riverines living in communities along the Madeira river Basin has been impacted by economic development in the last 40 years [6]. First came the gold rush of the 1980s, and then came the opening of roads, deforestation for agricultural projects, and construction of a great number of hydroelectric dams resulting in displacement and changes in traditional subsistence lifestyles. For all this region the Brazilian government has planned approximately 80 hydroelectric plants. Regardless of the scheduled date of construction, this activity will flood approximately $3 \%$ of the Amazon forest [6,7]. These programs and projects, along with immigration spurred by economic activities, are bringing rapid urbanization and changes in lifestyle, gradually replacing the traditional food supply chain that depended heavily on fish and natural foods abundant in the forest [8].

The rural inhabitants of the Madeira river, in Brazilian territory, have shown more dependence on fish, and as a result have consistently high hair- $\mathrm{Hg}$ concentrations [3]. The hair- $\mathrm{Hg}(\mathrm{HHg}$ ) concentrations of riverines living in the Madeira River Basin have been reviewed by Barbieri and Gardon [3]. In Bolivian territory, mean hair-Hg ranged from 1.9 to $8.7 \mathrm{ppm}$, whereas in Brazilian territory mean 
hair-Hg ranged from 10.2 to $15.2 \mathrm{ppm} \mathrm{[3].} \mathrm{The} \mathrm{high} \mathrm{HHg}$ values among Brazilian riverines represent a per capita fish consumption of 7 meals/week, contrasting with urban mothers with low fish consumption (1 meal/week) and attendant mean hair-Hg (5.4 ppm) concentration [3].

The concentrations of mercury in fish of the Amazon Basin vary greatly. A systematic comparison is riddled with difficulties related to fish habitat diversity, incomplete information (differences in local fish names from region to region, and insufficient knowledge of the fish feeding hierarchy) that includes fish size (length or weight) and age, which are important in controlling the random nature of fish sampling [9]. Indeed, when comparing rivers of the Amazon Basin, there are no salient features distinguishing fish from rivers impacted by intense gold-mining activities from the past, like the Madeira river, from fish caught in non-impacted waters [9]. Traditional subsistence villagers of the Madeira river are among the largest group of Amazonians in per capita fish consumption (ca. $148.2 \mathrm{~kg} / \mathrm{year}$ ); because of this elevated consumption, seasonal variability in fish availability has little impact on overall hair-Hg concentrations throughout the year [10].

The aim of this study is to assess mercury exposure, fish mercury concentrations and fish consumption habits in riverine populations inhabiting both sides of the Madeira river near the Santo Antônio hydroelectric power-plant, before flooding of the reservoir.

\section{Experimental Section}

\subsection{Background}

This cross-sectional descriptive study is part of a large interdisciplinary research project to integrate social, environmental, and health assessment of all riverine inhabitants of an area likely to be impacted by the Santo Antônio hydroelectric power-plant. This hydroelectric power-plant is being constructed at the Santo Antônio Falls, which is the last waterfall before Porto Velho city (state capital of Rondonia) and marks the beginning of the navigable stretch of the Madeira river until the Atlantic Ocean. The current National Developmental Program of the Brazilian Federal Government has planned the construction of two hydroelectric power-plants along the Madeira river in the state of Rondônia (Western Amazon): Santo Antônio (about $7 \mathrm{~km}$ upstream from Porto Velho city) and Jirau (120 km upstream from Santo Antônio falls). The Madeira river is the second largest river in the Amazon River Basin, and is its main tributary. It runs $1,459 \mathrm{~km}$ in Brazilian territory, has an average flow of $31,200 \mathrm{~m}^{3}$ per second $\left(5,000\right.$ to $\left.45,000 \mathrm{~m}^{3} \cdot \mathrm{s}^{-1}\right)$ and transports one of the largest loads of sediments in the world [11]. The research protocol, survey questionnaires and procedures were reviewed and approved by a Brazilian Research Ethics Committee (CAAE: 0010.0.047.000-09). After a comprehensive explanation, including the assurance that their involvement in this study was voluntary, consent forms were signed by the participants.

\subsection{Area of Study and Population}

Data were collected from May 2009 to April 2011 in the pre-impoundment phase of the Santo Antônio reservoir. Adults and children from riparian communities upstream and downstream of the dam project were surveyed. Fish were sampled in the area of Madeira river representing the most available species, which reflects the most consumed by the riverines. 
Figure 1 shows the study area, illustrating the four grouping of riparian communities regarding their proximity and location around the Santo Antônio falls where the dam project was being constructed. The studied communities occupy an area extending from Porto Velho city ( $8^{\circ} 47^{\prime} 31^{\prime \prime S}$ and 63⒌'7"W) to $220 \mathrm{~km}$ in both directions (up- and downstream) from the dam construction site. Some communities are more isolated or have fewer resources than others (i.e., energy, transportation, access to health services and education, and distance to food trade centers or grocery stores). We invited the all families from the communities upstream and downstream with direct influence from the projected dam to participate in the study. About 630 families that were invited and 495 families agreed to participate on a voluntary basis. The inclusion criterion was to have lived in these communities for at least one year. The exclusion criteria were any evident major neurological disease (auto referred, guaranteed or diagnosed by one of the researcher physicians) or those who refused to participate at any moment.

Figure 1. Illustration of the study area showing riparian communities regarding their proximity and location around the Santo Antônio falls. Area 1 (downstream the rapids, right bank), Area 2 (downstream the rapids, left bank), Area 3 (upstream the rapids, right bank), Area 4 (upstream the rapids, left bank) and the extractive reserve of the Cuniã Lake (Area 5), about $180 \mathrm{~km}$ downstream the rapids. Porto Velho city is the capital of Rondônia State.

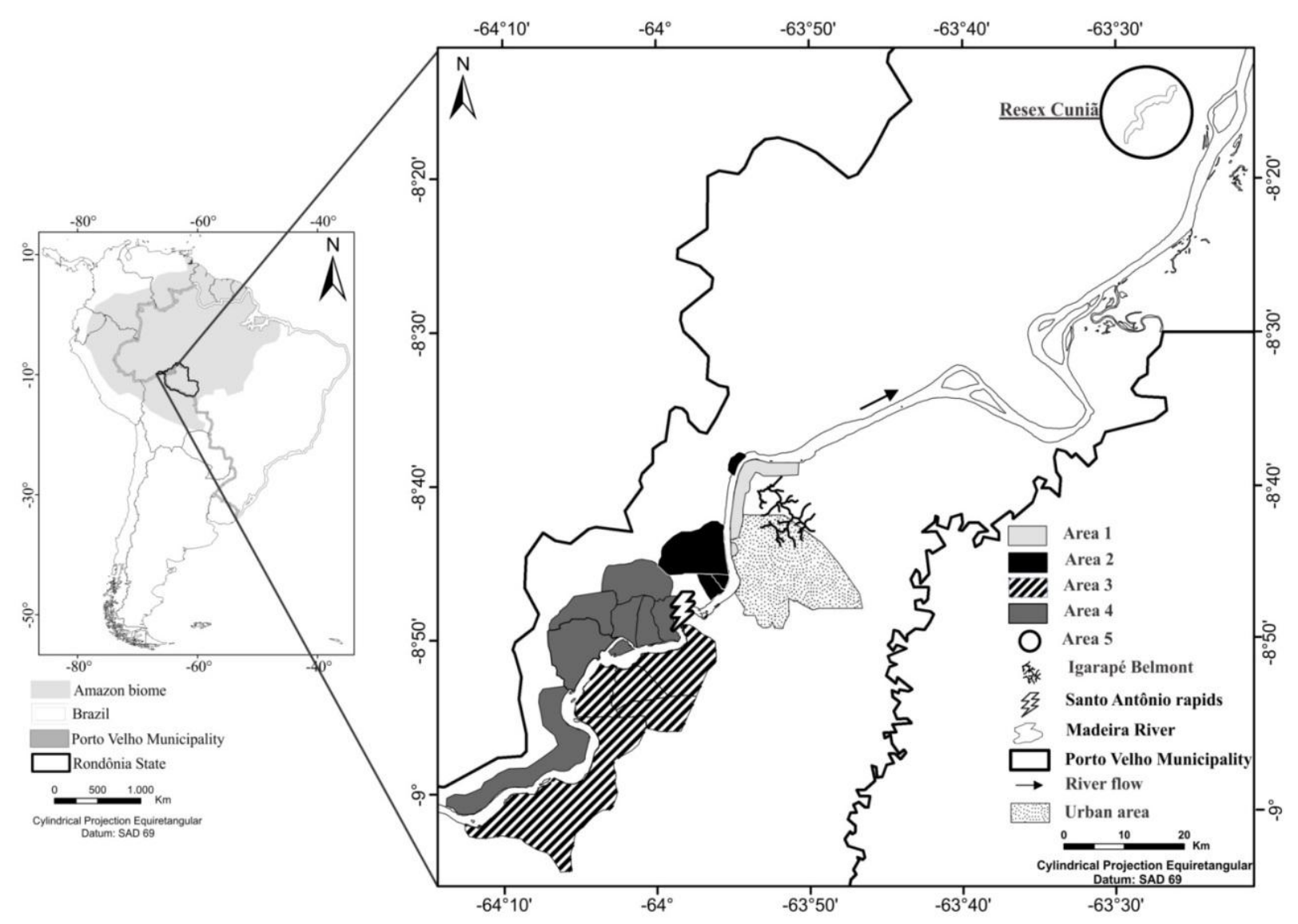

We grouped the communities into five areas, taking into account the left and right banks of the river, as well as spatial considerations regarding upstream and downstream. All the communities in the left bank had more difficulties to access transport, schools, health services and food variety than those 
from the right bank. Area 1 is located on the right bank downstream from the falls and incorporates, mainly, Belmont village (closest to the city of Porto Velho) with access by roads to the capital city on the right bank of Madeira river. Area 2 (left bank, downstream from the falls) comprises four villages close to the city of Porto Velho by boat (Novo Engenho Velho, São Sebastião, Balsa and Niterói villages). Area 2 has more difficulties to access roads and industrialized food. Area 3 (upstream from the falls on the right bank) comprises the five villages of Teotônio, Maria Auxiliadora, Princesa, Paulo Leal and Morrinhos with similar traditional food habits based in fish consumption, but more isolated than Area 2, having difficult access the main highway and to services and goods available in the capital city of Porto Velho. Area 4 (upstream from the falls on the left bank) comprises seven villages (Morrinhos, Amazonas, São Domingos, Cachoeira dos Macacos, Renascer, Ilha do Jatuarana, and Porto Seguro) that are more isolated than other villages. As a reference for typical traditional riverine living, we included an isolated community located in Cuniã Lake on the left side of the Madeira river (Area 5). This community is in a remote area, $180 \mathrm{~km}$ downstream from the capital city of Porto Velho. The ecological complex of Cuniã consists of more than 60 interconnected lakes in a total area of 55,850 ha and has a total estimated population of 309 individuals. It is the most remotely located of all assessed villages, with no means of regular transportation in the middle of the forest. Altogether, 2,008 individuals answered questionnaires and 1,945 individuals had hair samples collected in the studied areas.

\subsection{Questionnaire and Fish Intake Assessment}

A semi-structured questionnaire was applied to adults by trained interviewers; in all households with children an adult was invited to participate of the interview to collect information. Information concerning socioeconomic status, life style, demographics, occupational history, refereed morbidity and a dietary survey (including species of fish frequently consumed, and the consumption on the last $24 \mathrm{~h}$ ) was assessed. A specific question was about how many times the interviewed did eat fish last week. In general, the questionnaires took approximately $1 \mathrm{~h}$. The common names of fish species referred to by the interviewees were then classified according to the study by Bastos et al. (2008) [12] and, then, categorized with respect to mean total-Hg concentrations.

\subsection{Total-Hg Determination in Hair}

At the time of the interview we also collected a sample of hair cut from the occipital area near to the scalp. Total $\mathrm{Hg}$ concentration (hair-Hg) was determined in individual hair samples according to routine laboratory procedures at the Wolfgang Christian Pfeiffer Environmental Biogeochemical Laboratory (BIOGEOQ) at the Federal University of Rondônia (UNIR). Briefly, after mineralization in acid-oxidant medium, total $\mathrm{Hg}$ determination was performed by cold vapor atomic absorption spectrometry on a Perkin-Elmer (Ueberlingen, Germany) FIMS-400 ${ }^{\circledR}$ instrument [13]. For quality control, all analytical runs included material certified by the International Atomic Energy Agency (IAEA-085 and IAEA-086). Recovery rates were above $80 \%$ and detection limit below $0.03 \mathrm{mg} \cdot \mathrm{kg}^{-1}$. 


\subsection{Fish Sampling and Total-Hg Determination}

Fish samples were collected throughout the Madeira River Basin, covering a stretch of $230 \mathrm{~km}$ (downstream and upstream of the falls) and from Cuniã Lake. Fish specimens $(\mathrm{N}=1,599)$ were captured at the time of the study and taxa were identified by the Ichthyofauna Laboratory of the University of Rondônia according to Santos et al. [14].

Determination of total $\mathrm{Hg}$ concentration in fish muscle was done according to routine procedures developed by Bastos et al. [13]. Briefly, fish samples were mineralized in an acid-oxidative medium and digested for $60 \mathrm{~min}$ in a block digester at $80{ }^{\circ} \mathrm{C}$ (Tecnal, Mod. 007A, São Paulo, Brazil). Total $\mathrm{Hg}$ measurements were carried out by cold vapor atomic absorption spectrophotometry (Flow Injection Mercury System, Perkin Elmer FIMS-400 ${ }^{\circledR}$ ). Precision and accuracy were ensured by using internal standards against certified reference materials (Dogfish Muscle, DORM-2, National Research Council of Canada, Ottawa, ON, Canada), which have been used in intercalibration exercises among Brazilian laboratories showing detection limit below $0.001 \mathrm{mg} \mathrm{kg}^{-1}$. Daily calibration and method verification was done with known concentration standards.

\subsection{Data Analysis}

The characteristics of the communities, the fish consumption habits and the HHg concentration and $\mathrm{Hg}$ concentration in different fish species were analyzed using descriptive statistics. The results of $\mathrm{HHg}$ were stratified by age groups and the hair $\mathrm{Hg}$ values were expressed as median and the 5 and 95th percentiles. Because of non-normal data distribution of main variables, data analysis was based on non-parametric statistical tests. The Spearman's correlation analysis was applied to assess association between fish consumption and HHg. Graphics and statistics were performed using SPSS $^{\circledR} 20.0$ software for MAC. Statistical results were considered significant when $p<0.05$.

\section{Results and Discussion}

The sample was composed by 2,008 individuals who answered questionnaires and 1,945 individuals had hair samples collected in the studied areas. From the 630 families living in the selected areas, 495 families agreed to participate with a total of 1,945 individuals. The general acceptance rate of the communities ranged from $79 \%$ to $90 \%$. The sample population consisted of $41 \%$ riverside children and teenage and $59 \%$ of adults, being $41 \%$ of female and $51 \%$ of male.

\subsection{Characteristic of the Riverine Population and Exposure}

In general, some socio-demographic and socio-economic characteristics of the riverine communities were similar. Spatially, all the communities live on the river banks. However, their access to the urban area may influence on their fish consumption. This was the reason why we considered separately the left and right banks of the Madeira river in this study. For the communities living in the left bank, it is more difficult to access other sources of protein besides fish consumption. Table 1 summarizes general characteristics of the population. 
Table 1. Characteristics of the study population.

\begin{tabular}{|c|c|c|c|c|c|}
\hline Grouped Villages & Area 1 & Area 2 & Area 3 & Area 4 & Resex Cuniã \\
\hline $\begin{array}{l}\text { Position along the } \\
\text { Madeira river }\end{array}$ & $\begin{array}{l}\text { Downstream the } \\
\text { waterfalls }\end{array}$ & $\begin{array}{l}\text { Downstream the } \\
\text { waterfalls }\end{array}$ & $\begin{array}{l}\text { Upstream the } \\
\text { Santo Antônio } \\
\text { waterfall }\end{array}$ & $\begin{array}{l}\text { Upstream the } \\
\text { Santo Antônio } \\
\text { waterfall }\end{array}$ & $\begin{array}{l}\text { Downstream the } \\
\text { Santo Antônio } \\
\text { waterfall }\end{array}$ \\
\hline Riverside margin & Right & Left & Right & Left & Lakes on left \\
\hline $\begin{array}{l}\text { Access to urban area in } \\
\text { Porto Velho city }\end{array}$ & $\begin{array}{l}7-10 \text { km away } \\
\text { from the urban } \\
\text { area; } \\
\text { road available in } \\
\text { dry seasons; } \\
\text { viable by bike }\end{array}$ & $\begin{array}{l}8-15 \mathrm{~km} \text { away } \\
\text { from the urban } \\
\text { area; } \\
\text { road available in } \\
\text { dry seasons; } \\
\text { viable by bike } \\
\text { (ferry available } \\
\text { daily) }\end{array}$ & $\begin{array}{l}20-30 \mathrm{~km} \text { away } \\
\text { from the urban } \\
\text { area; } \\
\text { road available }\end{array}$ & $\begin{array}{l}25-50 \mathrm{~km} \text { from } \\
\text { the urban area; } \\
\text { road available in } \\
\text { dry seasons until } \\
\text { the ferry in Area } 2\end{array}$ & $\begin{array}{l}180 \mathrm{~km} \text { from } \\
\text { urban area; } \\
\text { no road } \\
\text { available; } \\
\text { viable only by } \\
\text { boat } \\
\text { (very difficult in } \\
\text { dry season) }\end{array}$ \\
\hline Main source of fish & Belmont $* *$ & Madeira river & Madeira river & Madeira river & Cuniã lake \\
\hline $\begin{array}{l}\text { Assessed individuals } \\
\text { (total; \% of children) } *\end{array}$ & $276 ; 40.6 \%$ & $343 ; 46.4 \%$ & $667 ; 43.2 \%$ & $471 ; 39.7 \%$ & $251 ; 45.8 \%$ \\
\hline $\begin{array}{l}\text { Residence time on site } \\
\text { (years) }\end{array}$ & $16(1-50)$ & $21(1-47)$ & $15(2-53)$ & $14(2-52)$ & $30(4-63)$ \\
\hline $\begin{array}{l}\text { Sewer system and safe } \\
\text { drinking water supply }\end{array}$ & No & No & No & No & No \\
\hline $\begin{array}{l}\text { Local primary-health- } \\
\text { care unit }\end{array}$ & No & Yes & Yes & No & No \\
\hline
\end{tabular}

Education of the adults in years (proportional\% frequency)

\begin{tabular}{llllll}
\hline Illiterate & $11.0 \%$ & $8.5 \%$ & $9.7 \%$ & $11.8 \%$ & $7.8 \%$ \\
\hline 1-3 years (literate) & $10.4 \%$ & $17.0 \%$ & $21.2 \%$ & $20.9 \%$ & $13.5 \%$ \\
\hline 4-9 years & $49.2 \%$ & $51.2 \%$ & $56.9 \%$ & $55.2 \%$ & $65.3 \%$ \\
\hline 10 years or more & $29.4 \%$ & $23.1 \%$ & $12.3 \%$ & $11.1 \%$ & $13.5 \%$ \\
\hline $\begin{array}{l}\text { Family income } \\
\text { (R\$/month) *** }\end{array}$ & 1000 & 1000 & 850 & 930 & 600 \\
\hline
\end{tabular}

\begin{tabular}{|c|c|c|c|c|c|}
\hline \multicolumn{6}{|c|}{ Main occupation of adults (proportional \% frequency) } \\
\hline Fishing & $6.1 \%$ & $11.1 \%$ & $19.0 \%$ & $27.9 \%$ & $29.3 \%$ \\
\hline Goldmining & $6.1 \%$ & $0 \%$ & $0.3 \%$ & $0 \%$ & $0 \%$ \\
\hline Farming & $11.0 \%$ & $6.0 \%$ & $21.8 \%$ & $18.6 \%$ & $11.4 \%$ \\
\hline Extractivism & $0 \%$ & $0 \%$ & $0 \%$ & $0.8 \%$ & $0.7 \%$ \\
\hline Building & $2.5 \%$ & $1.5 \%$ & $0.9 \%$ & $0 \%$ & $0 \%$ \\
\hline Studying & $6.1 \%$ & $6.0 \%$ & $6.0 \%$ & $4.6 \%$ & $6.4 \%$ \\
\hline Home & $25.8 \%$ & $30.7 \%$ & $22.2 \%$ & $27.5 \%$ & $20.0 \%$ \\
\hline Variable (seasonal) & $47.9 \%$ & $44.7 \%$ & $29.7 \%$ & $20.5 \%$ & $32.1 \%$ \\
\hline
\end{tabular}

Notes: Santo Antônio waterfall (rapids) is the last before Porto Velho city and marks the beginning of the navigable stretch of Madeira river; Values expressed as median (5-95th percentiles); * Adults when age > 16 year; Children when age $<17$ year; ** Belmont stream (Belmont igarapé) is the main tributary of the Madeira river in the area immediately downriver from the Santo Antônio waterfall; $* * * \mathrm{R} \$=\mathrm{BRL}=$ Brazilian Real; Family income $=\sum$ income within family. 
The areas with the most difficult access or most distant from the city of Porto Velho showed a proportionally higher number of adults engaged in fishing activities (Area $5>$ Area $4>$ Area3), and proportionally more people with $<10$ years of schooling, and lower family income; they tended to depend more on the river and the forest for their livelihood and are the ones with higher median hair-Hg concentrations. Overall, these areas shared a simple life, housing without basics indoor sanitary facilities, lack of access to safe drinking water supply; in only two (Areas 2 and 3) there were limited primary health-care facilities. In all studied areas the residence time ranged from 1 to 63 years. The Areas 4 and 5 are the most isolated ones.

A summary of data on frequency of fish consumption and attendant $\mathrm{Hg}$ exposure $(\mathrm{HHg})$ is shown in Table 2 and Figure 2. The study showed that in these riverine communities daily fish consumption is more prevalent than in the other areas. To better illustrate the overall $\mathrm{HHg}$ of each area we organized the data into: preschool children ( 0 to 5 years), children (6 to 15 years), adults of both sexes (>16 years); we also categorized women of childbearing age because of vulnerability to prenatal exposure to fish-mercury (16 to 49 years).

Table 2. Regular fish consumption and total-Hg concentration in riparians' hair from Madeira River Basin.

\begin{tabular}{|c|c|c|c|c|c|}
\hline Grouped Villages & Area 1 & Area 2 & Area 3 & Area 4 & Resex Cuniã \\
\hline \multicolumn{6}{|l|}{ Fish consumption } \\
\hline Never eat fish & $5.1 \%$ & $3.0 \%$ & $2.9 \%$ & $2.4 \%$ & $0.0 \%$ \\
\hline Fish $1 / 15$ days & $27.0 \%$ & $20.1 \%$ & $20.6 \%$ & $17.1 \%$ & $1.6 \%$ \\
\hline Fish 3-5/week & $43.1 \%$ & $36.4 \%$ & $32.1 \%$ & $33.2 \%$ & $19.4 \%$ \\
\hline Fish $>3 /$ week & $19.0 \%$ & $27.2 \%$ & $18.2 \%$ & $24.2 \%$ & $21.4 \%$ \\
\hline Daily eat fish & $5.8 \%$ & $13.3 \%$ & $26.1 \%$ & $23.1 \%$ & $57.7 \%$ \\
\hline \multicolumn{6}{|l|}{ Hair-Hg (ppm) } \\
\hline \multirow[t]{2}{*}{ Age $\leq 5$ years } & 1.9 & 2.01 & 3.7 & 4.2 & 4.9 \\
\hline & $(1.4-2.4) / 3 *$ & $(0.4-8.4) / 10 *$ & $(0.4-23.2) / 52$ & $(0.4-43.6) / 42$ & $(0.9-14.4) / 30$ \\
\hline \multirow[t]{2}{*}{ Age $6-16$ years } & 1.9 & 3.9 & 3.6 & 4.1 & 5.3 \\
\hline & $(0.2-8.2) / 109$ & $(0.4-14.7) / 136$ & $(0.4-31.7) / 225$ & $(0.2-35.3) / 135$ & $(1.7-14.3) / 84$ \\
\hline \multirow[t]{2}{*}{ Age $>16$ years } & 2.9 & 4.8 & 5.3 & 5.7 & 8.2 \\
\hline & $(0.2-17.7) / 162$ & $(0.4-16.7) / 182$ & $(0.3-27.6) / 364$ & $(0.5-37.2) / 276$ & $(1.7-19.4) / 135$ \\
\hline \multirow[t]{2}{*}{ Female $13-49$ years $* *$} & 2.4 & 3.5 & 4.0 & 3.5 & 5.3 \\
\hline & $(0.3-17.5) / 156$ & $(0.4-10.8) / 164$ & $(0.3-26.1) / 307$ & $(0.2-26.8) / 204$ & $(1.6-13.4) / 111$ \\
\hline \multirow[t]{2}{*}{ Altogether } & 2.3 & 4.3 & 4.6 & 5.3 & 6.3 \\
\hline & $(0.2-14.6) / 274$ & $(0.4-15.6) / 328$ & $(0.3-27.9) / 641$ & $(0.3-37.1) / 453$ & $(1.7-17.2) / 249$ \\
\hline Comparing areas $* * *$ & 1 & 2 & $2-3$ & $3-4$ & 5 \\
\hline Rank correlation $* * * *$ & $0.239(p<0.001)$ & $0.105(p=0.059)$ & $0.056(p=0.158)$ & $0.113(p=0.018)$ & $0.120(p=0.061)$ \\
\hline
\end{tabular}

Notes: Age limits included. Hair-Hg values expressed as median (5-96th percentiles)/number of individuals whose hair sample was analyzed; * Range exceptionally expressed as minimum-maximum; ** Usual female's childbearing age considering mean menopause age $=50$ years [15]; $* * *$ The numbers $(1-5)$ represent significantly different groups at Mann Whitney U test with respect to hair-Hg concentration; **** Spearman's rank correlation analysis between fish consumption and hair-Hg concentration: rho correlation coefficient ( $p$ value). 
Figure 2. Box-plot representation of total hair- $\mathrm{Hg}$ concentrations in the studied population $\left(\mathrm{ppm} \mathrm{w} / \mathrm{w}=\mathrm{mg} \cdot \mathrm{kg}^{-1}\right)$.

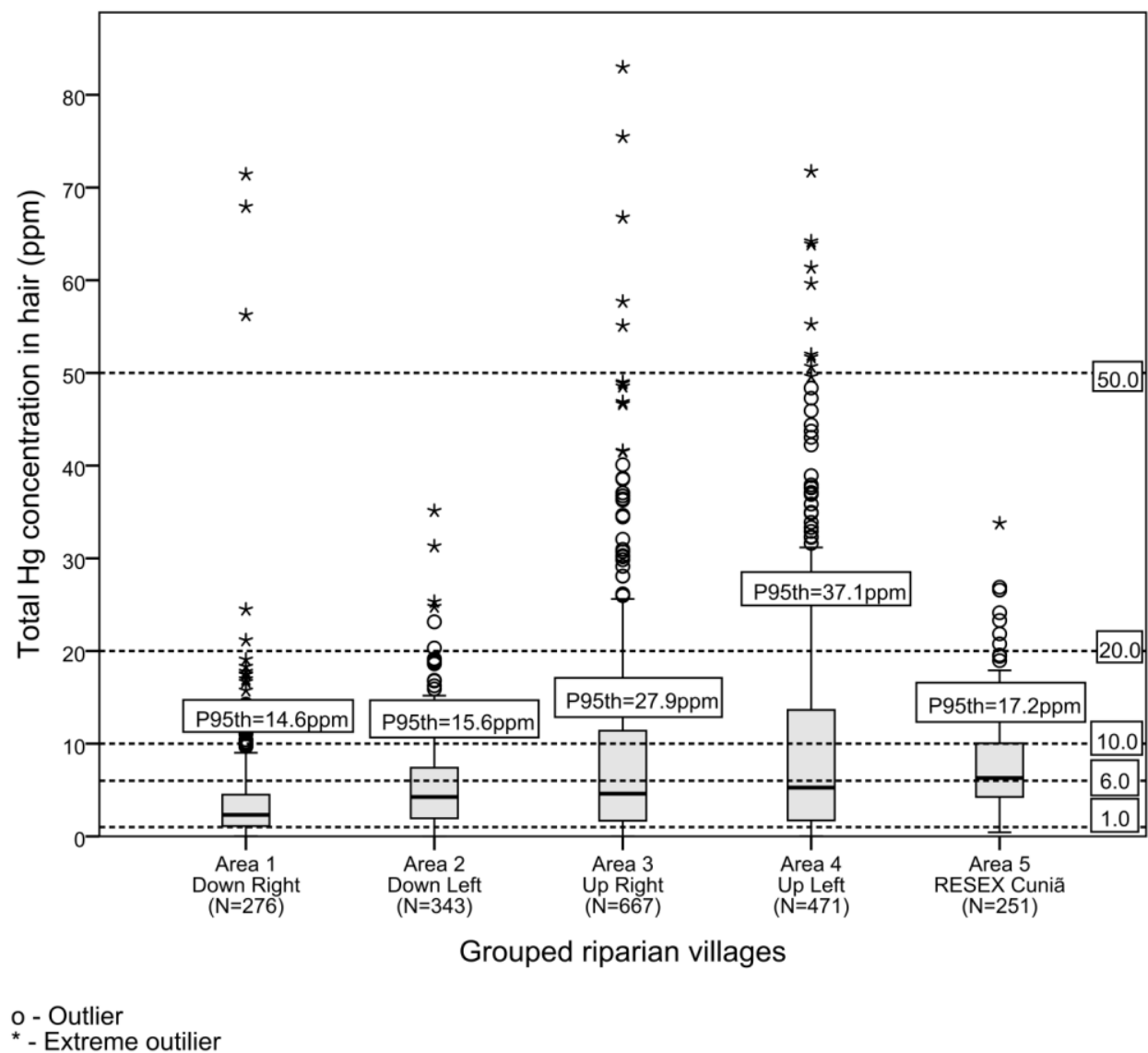

Reported daily fish consumption was substantially higher for the Cuniã riverines ( $\mathrm{ca}$. 58\%), relatively less for Areas 3 and 4 (26\% and 23\% respectively), and much less for Areas 1 and 2. However, the pattern of $\mathrm{HHg}$ aggregated for each area showed that $\mathrm{HHg}$ concentrations were significantly higher in some than in others (Area $5>$ Area $4>$ Area 3). With respect to $\mathrm{Hg}$ exposure, the significantly lowest $(\mathrm{HHg})$ was seen in Area $1(p<0.001)$ with both the lowest median and 95th percentile values (respectively: 2.3 and $14.6 \mathrm{ppm}$ ). Contrasting with the lower median $\mathrm{HHg}$ values found in Areas 1 and 2 (near Porto Velho city), Areas 3 and 4 showed the highest data dispersion, 95th percentiles. Considering all individuals (age groups and both sexes), fish consumption and $\mathrm{HHg}$ showed a statistically significant correlation only in Areas 1 and 4 with the correlation coefficient of $24 \%$ and $11 \%$, respectively, as presented in Table 2.

Communities were grouped as upstream or downstream the dam and also as left or right riverside. Resex Cuniã: lacustrine reference area $180 \mathrm{~km}$ downstream Porto Velho. Boxplots: quartiles (Figure 2). One value (upstream the dam, left side) was excluded from the graphic because it showed atypical extreme value (124.3 ppm). Empirical limits: $1 \mathrm{ppm}$ in hair of women of child-bearing age in the US, equivalent to the USEPA reference dose (RfD) of $0.1 \mu \mathrm{g} / \mathrm{kg} / \mathrm{day}$ ); $6 \mathrm{ppm}$ (maternal hair-Hg associated to a 3-point decrement in IQ according [16,17]); $10 \mathrm{ppm}$ (maternal hair-Hg associated with $5 \%$ risk for children with basis on Iraqi data); $20 \mathrm{ppm}$ (twice the WHO limit for maternal hair) and $50 \mathrm{ppm}$ (associated with a 5\% risk of neurological damage to adults) [18]. 
Figure 3 illustrates the distribution of $\mathrm{HHg}$, reflecting the level of subsistence and/or traditionalism (fish consumption habits). Of the 1,945 analyzed hair samples, 17 individuals $(0.9 \%)$ showed $\mathrm{HHg}>50 \mathrm{ppm}, 154(7.9 \%) \mathrm{HHg}>20$ ppm, $556(28.6 \%) \mathrm{HHg}>10 \mathrm{ppm}$ and 1,750 (90.0\%) HHg > $1 \mathrm{ppm}$. Indeed, the most traditional riverines living in Cuniã (Area 5) showed the highest median $\mathrm{HHg}(6.30 \mathrm{ppm})$ compared to other riverine communities. In fact, in different age groups, the communities nearest the city of Porto Velho showed the lowest median HHg values. Regarding the pattern of distribution of $\mathrm{HHg}$ values, however, there were two extreme conditions shown in Figure 3: one is represented by communities in Areas 1 and 2, contrasting with the traditional Cuniã, showing a distinct pattern of $\mathrm{HHg}$ distribution; in this traditional community almost $70 \%$ showed $\mathrm{HHg}$ above 5 ppm. The other distant communities of Areas 3 and 4 showed respectively 55\% and 50\% of samples above 5 ppm.

Figure 3. Percent distribution of hair-Hg concentrations illustrating the four village groups. Area 1 (downstream the rapids, right bank), Area 2 (downstream the rapids, left bank), Area 3 (upstream the rapids, right bank), Area 4 (upstream the rapids, left bank) and the extractive reserve of the Cuniã Lake (Area 5), about $180 \mathrm{~km}$ downstream the rapids. Porto Velho city is the capital of Rondônia State.

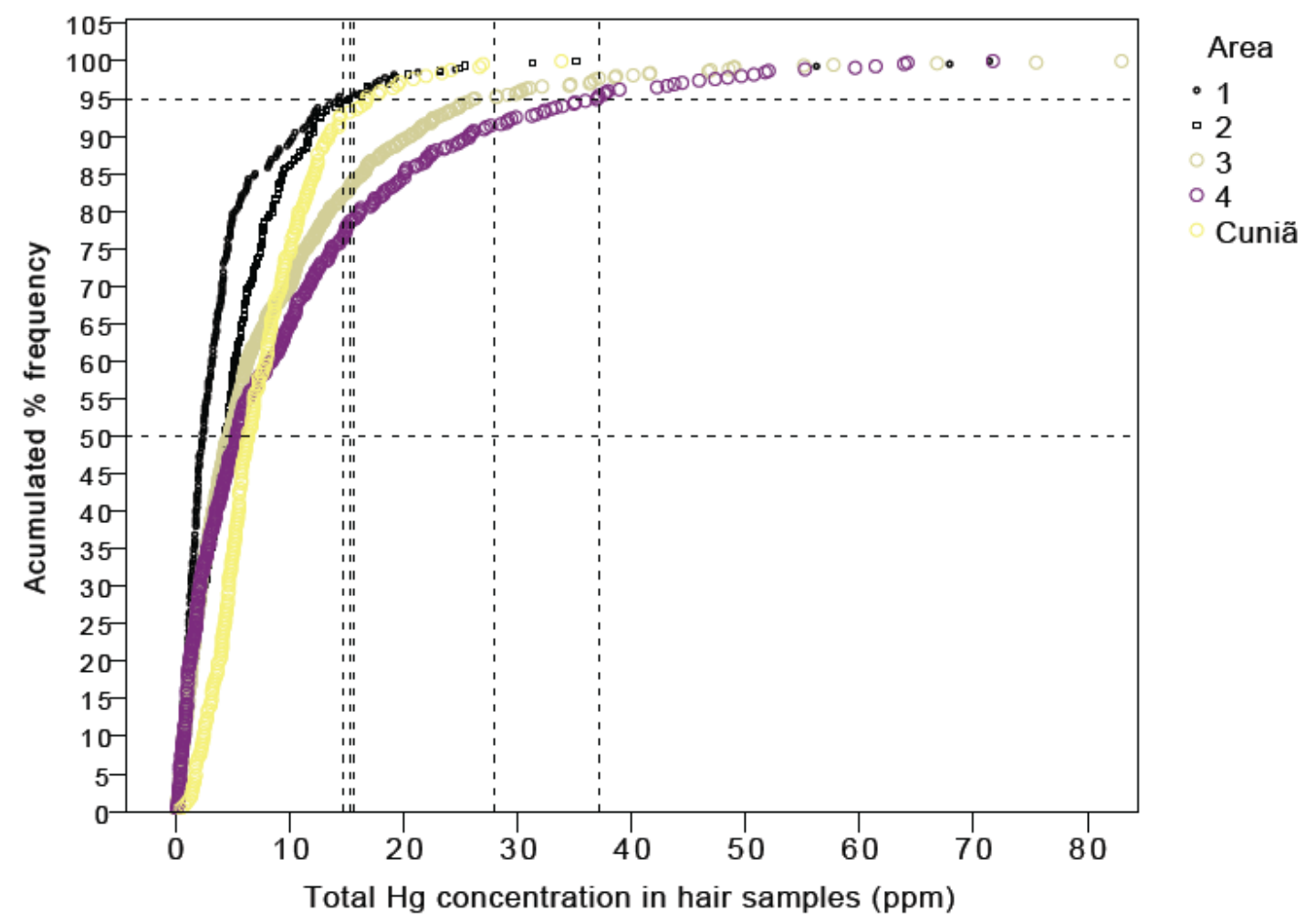

\subsection{Fish Mercury Concentration}

Total-Hg concentrations in fish-muscle were species-specific; a detailed account of 110 species caught throughout the Madeira River Basin, covering a stretch of $230 \mathrm{~km}$ (downstream and upstream of the falls) and from Cuniã Lake is shown in Table 3. The Figure 4 summarizes abundance of catch and $\mathrm{Hg}$ concentrations as a function of fish feeding strategy. Species at the top of the food chain 
classified by groups (carnivorous and piscivorous) showed the highest median muscle $\mathrm{Hg}$ concentrations (respectively $0.68 \mathrm{ppm}$ and $0.37 \mathrm{ppm}$ ), while species at the bottom of the food chain (detritivorous and herbivorous) showed the lowest median $\mathrm{Hg}$ concentrations (respectively $0.06 \mathrm{ppm}$, and $0.09 \mathrm{ppm}$ ). However, regarding abundance of fish (percent catch) the most frequent groups were not necessarily the ones with higher median $\mathrm{Hg}$ concentrations. Indeed, 53\% of the catch was found in two groups (omnivorous, 28.8\%; detritivorous, 24.5\%) with the lowest median $\mathrm{Hg}$ concentrations (Figure 4).

Table 3. List of fish species (likely consumed) caught at 15 locations along the Madeira River Basin during the studied period and respective total $\mathrm{Hg}$ concentrations $(\mu \mathrm{g} / \mathrm{g})$.

\begin{tabular}{|c|c|c|c|c|c|c|c|}
\hline $\begin{array}{l}\text { Scientific } \\
\text { Name }\end{array}$ & $\begin{array}{l}\text { Feeding } \\
\text { Behavior }\end{array}$ & $\mathbf{N}$ & Mean & $\begin{array}{l}\text { Standard } \\
\text { Deviation }\end{array}$ & $\begin{array}{c}{[\mathrm{Hg}],} \\
\text { Median }\end{array}$ & Minimum & Maximum \\
\hline Acestrorhynchus sp. & Carnivorous & 77 & 0.41 & 0.28 & 0.37 & 0.09 & 1.27 \\
\hline Ageneiosus sp. & Carnivorous & 21 & 0.41 & 0.29 & 0.39 & 0.02 & 0.88 \\
\hline Anodus sp. & Detritivorous & 42 & 0.43 & 0.15 & 0.40 & 0.17 & 0.75 \\
\hline Argonectes sp. & Omnivorous & 1 & 0.51 & & 0.51 & & \\
\hline Auchenipterichthys sp. & Omnivorous & 120 & 0.11 & 0.06 & 0.10 & 0.04 & 0.54 \\
\hline Auchenipterus sp. & Insectivorous & 35 & 0.39 & 0.26 & 0.35 & 0.10 & 0.93 \\
\hline Brachyplatystoma sp. & Carnivorous & 114 & 1.58 & 1.13 & 1.33 & 0.12 & 4.89 \\
\hline Brycon sp. & Omnivorous & 5 & 0.08 & 0.02 & 0.08 & 0.05 & 0.11 \\
\hline Bryconops sp. & Omnivorous & 11 & 0.18 & 0.09 & 0.15 & 0.06 & 0.38 \\
\hline Calophysus sp. & Omnivorous & 10 & 0.92 & 0.32 & 0.82 & 0.54 & 1.44 \\
\hline Centromochlus sp. & Insectivorous & 2 & 0.22 & 0.09 & 0.22 & 0.16 & 0.29 \\
\hline Chalceus sp. & Insectivorous & 2 & 0.11 & 0.01 & 0.11 & 0.11 & 0.12 \\
\hline Cichla sp. & Carnivorous & 7 & 0.50 & 0.32 & 0.45 & 0.17 & 1.14 \\
\hline Colossoma sp. & Herbivorous & 2 & 0.04 & 0.01 & 0.04 & 0.03 & 0.04 \\
\hline Curimata sp. & Detritivorous & 15 & 0.09 & 0.04 & 0.07 & 0.04 & 0.16 \\
\hline Curimatella sp. & Detritivorous & 11 & 0.07 & 0.03 & 0.06 & 0.04 & 0.11 \\
\hline Cynodon sp. & Carnivorous & 7 & 0.89 & 0.44 & 1.08 & 0.26 & 1.47 \\
\hline Geophagus sp. & Omnivorous & 4 & 0.18 & 0.06 & 0.21 & 0.09 & 0.23 \\
\hline Hemiodus sp. & Detritivorous & 79 & 0.08 & 0.11 & 0.05 & 0.01 & 0.68 \\
\hline Hemisorubim sp. & Carnivorous & 2 & 0.71 & 0.15 & 0.71 & 0.60 & 0.81 \\
\hline Heros sp. & Carnivorous & 6 & 0.22 & 0.05 & 0.21 & 0.18 & 0.31 \\
\hline Hoplias sp. & Carnivorous & 18 & 0.30 & 0.12 & 0.26 & 0.15 & 0.54 \\
\hline Hydrolycus sp. & Carnivorous & 11 & 1.29 & 0.67 & 1.20 & 0.38 & 2.90 \\
\hline Hypoclinemus sp. & Insectivorous & 3 & 0.25 & 0.11 & 0.31 & 0.13 & 0.32 \\
\hline Hypophthalmus sp. & Detritivorous & 23 & 0.69 & 0.25 & 0.71 & 0.19 & 1.11 \\
\hline Hypoptopoma sp. & Detritivorous & 14 & 0.04 & 0.01 & 0.03 & 0.02 & 0.05 \\
\hline Hypostomus sp. & Detritivorous & 1 & 0.02 & & 0.02 & & \\
\hline Ilisha sp. & Carnivorous & 2 & 0.88 & 0.01 & 0.88 & 0.87 & 0.89 \\
\hline
\end{tabular}


Table 3. Cont.

\begin{tabular}{|c|c|c|c|c|c|c|c|}
\hline $\begin{array}{l}\text { Scientific } \\
\text { Name }\end{array}$ & $\begin{array}{l}\text { Feeding } \\
\text { Behavior }\end{array}$ & $\mathbf{N}$ & Mean & $\begin{array}{l}\text { Standard } \\
\text { Deviation }\end{array}$ & $\begin{array}{l}{[\mathrm{Hg}] \text {, }} \\
\text { Median }\end{array}$ & Minimum & Maximum \\
\hline Jurengraulis sp. & Detritivorous & 22 & 0.09 & 0.05 & 0.07 & 0.05 & 0.26 \\
\hline Laemolyta sp. & Detritivorous & 13 & 0.26 & 0.11 & 0.24 & 0.09 & 0.42 \\
\hline Leporinus sp. & Omnivorous & 16 & 0.09 & 0.07 & 0.06 & 0.03 & 0.27 \\
\hline Loricaria sp. & Detritivorous & 4 & 0.12 & 0.04 & 0.13 & 0.07 & 0.16 \\
\hline Loricariichthys sp. & Detritivorous & 2 & 0.14 & 0.09 & 0.14 & 0.08 & 0.21 \\
\hline Mesonauta sp. & Omnivorous & 1 & 0.46 & & 0.46 & & \\
\hline Metynnis sp. & Omnivorous & 3 & 0.17 & 0.11 & 0.18 & 0.05 & 0.28 \\
\hline Myloplus sp. & Herbivorous & 1 & 0.03 & & 0.03 & & \\
\hline Mylossoma sp. & Herbivorous & 70 & 0.07 & 0.04 & 0.06 & 0.02 & 0.19 \\
\hline Nemadoras sp. & Omnivorous & 48 & 0.44 & 0.23 & 0.43 & 0.07 & 0.90 \\
\hline Opsodoras sp. & Omnivorous & 8 & 0.38 & 0.20 & 0.29 & 0.20 & 0.78 \\
\hline Oxydoras sp. & Omnivorous & 10 & 0.13 & 0.09 & 0.10 & 0.06 & 0.30 \\
\hline Parauchenipterus sp. & Insectivorous & 5 & 0.10 & 0.07 & 0.10 & 0.04 & 0.22 \\
\hline Pellona sp. & Carnivorous & 23 & 0.72 & 0.39 & 0.66 & 0.19 & 1.56 \\
\hline Piaractus sp. & Herbivorous & 1 & 0.11 & & 0.11 & & \\
\hline Pimelodus sp. & Omnivorous & 108 & 0.21 & 0.09 & 0.20 & 0.05 & 0.53 \\
\hline Pinirampus sp. & Carnivorous & 10 & 1.55 & 0.40 & 1.64 & 0.79 & 2.03 \\
\hline Plagioscion sp. & Carnivorous & 11 & 0.59 & 0.19 & 0.63 & 0.34 & 0.83 \\
\hline Potamorhina sp. & Detritivorous & 149 & 0.12 & 0.05 & 0.11 & 0.01 & 0.41 \\
\hline Prochilodus sp. & Detritivorous & 53 & 0.09 & 0.06 & 0.07 & 0.02 & 0.41 \\
\hline Psectrogaster sp. & Detritivorous & 69 & 0.15 & 0.11 & 0.13 & 0.03 & 0.89 \\
\hline Pseudoplatystoma sp. & Carnivorous & 7 & 0.63 & 0.52 & 0.41 & 0.25 & 1.74 \\
\hline Pterodoras sp. & Herbivorous & 5 & 0.01 & 0.00 & 0.01 & 0.01 & 0.01 \\
\hline Pterygoplichthys sp. & Detritivorous & 13 & 0.08 & 0.04 & 0.07 & 0.03 & 0.16 \\
\hline Pygocentrus sp. & Carnivorous & 30 & 0.26 & 0.15 & 0.21 & 0.07 & 0.81 \\
\hline Rhaphiodon sp. & Carnivorous & 39 & 1.19 & 0.97 & 1.03 & 0.21 & 6.06 \\
\hline Rhytiodus sp. & Herbivorous & 3 & 0.02 & 0.01 & 0.02 & 0.02 & 0.03 \\
\hline Roeboides sp. & Carnivorous & 3 & 0.33 & 0.20 & 0.38 & 0.11 & 0.49 \\
\hline Roestes sp. & Carnivorous & 3 & 0.42 & 0.18 & 0.40 & 0.25 & 0.61 \\
\hline Satanoperca sp. & Insectivorous & 8 & 0.13 & 0.04 & 0.14 & 0.06 & 0.19 \\
\hline Schizodon sp. & Herbivorous & 18 & 0.27 & 0.25 & 0.13 & 0.01 & 0.76 \\
\hline Semaprochilodus sp. & Detritivorous & 5 & 0.16 & 0.05 & 0.15 & 0.10 & 0.23 \\
\hline Serrasalmus sp. & Carnivorous & 59 & 0.41 & 0.31 & 0.34 & 0.02 & 1.70 \\
\hline Sorubim sp. & Carnivorous & 19 & 0.57 & 0.21 & 0.57 & 0.22 & 0.97 \\
\hline Tatia sp. & Carnivorous & 1 & 0.08 & & 0.08 & & \\
\hline Trachydoras sp. & Omnivorous & 1 & 0.18 & & 0.18 & & \\
\hline Triportheus sp. & Omnivorous & 99 & 0.28 & 0.25 & 0.17 & 0.04 & 1.04 \\
\hline Zungaru sp. & Carnivorous & 2 & 0.75 & 0.46 & 0.75 & 0.43 & 1.08 \\
\hline
\end{tabular}


Figure 4. Box-plot representation of total-Hg concentrations in fish-muscle of 110 species caught at the 15 sampling sites as a function of fish feeding strategy.

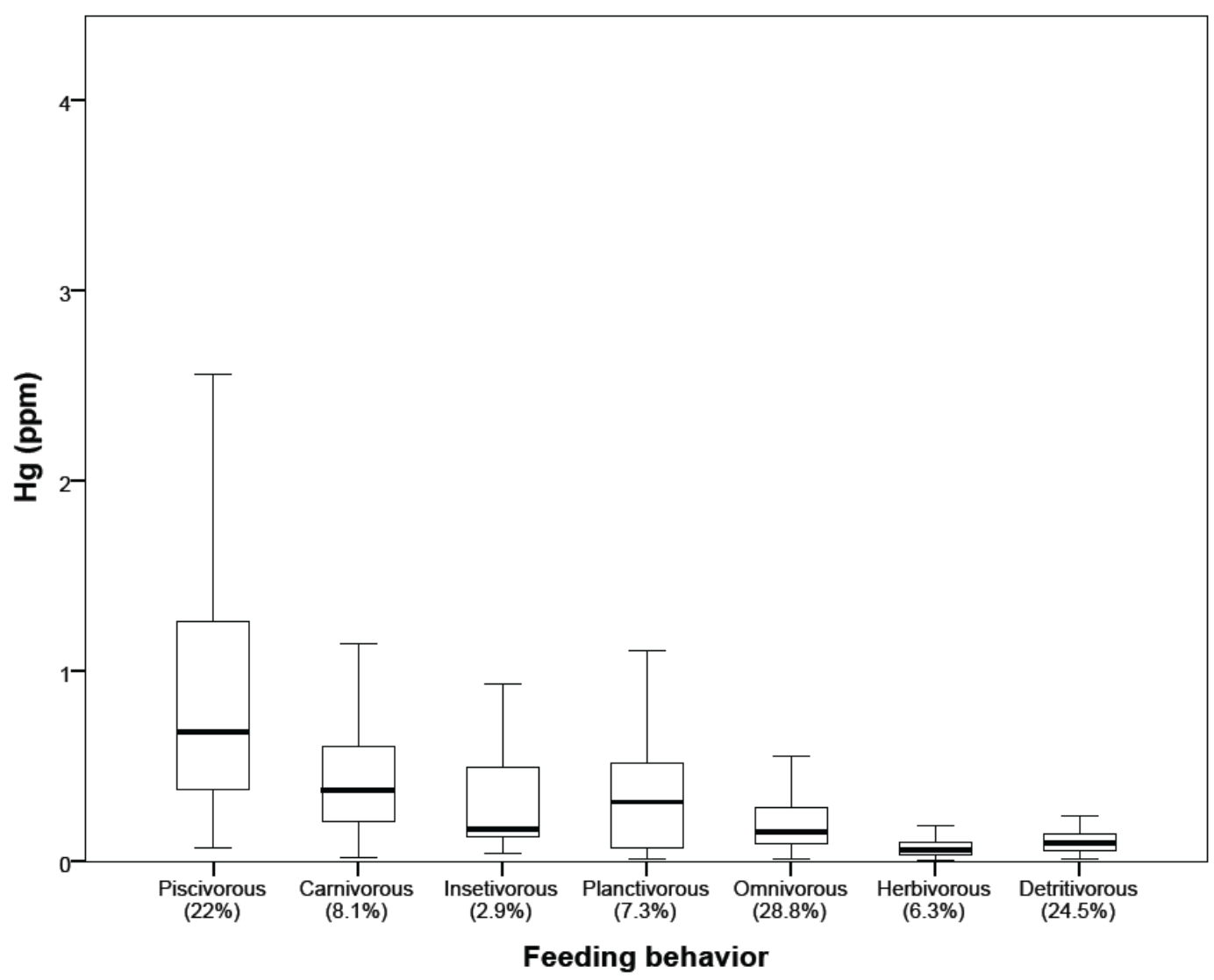

\subsection{Discussion}

This study represents one of the largest surveys of riverine populations in the Brazilian Amazon with respect to hair-Hg concentrations. Despite the changes of economic development that is occurring in Western Amazon, fish is still the main source of protein and the principal means of exposure to $\mathrm{MeHg}$ for riverines of the Madeira river. Elevated hair-Hg concentrations, according to WHO guidelines (2008) were found in all studied communities. Fish consumption habits influence HHg and is influenced by lifestyle (isolation and subsistence on forest and river resources). Nevertheless, this survey suggests that overall fish consumption ( $\mathrm{HHg}$ ) has diminished in comparison to studies done in the last 15 years [19-21]. In the Brazilian Amazon few studies on $\mathrm{Hg}$ exposure in riverine populations have addressed the issue of health effects based on epidemiological study (longitudinal cohort study on early childhood $\mathrm{Hg}$ exposure. This is due to the difficulty in working in remote regions (long distance from the urban areas, where the transportation usually is by boat). Yet, in these remote areas the population's access to health services is almost non-existent, the deliveries are made by midwives and $\mathrm{Hg}$ exposure in children, women of child-bearing and pregnant women have been a cause of great concern because these groups are particularly vulnerable. We know that during the pregnancy $\mathrm{MeHg}$ readily crosses the placental barrier and also because the toxicological effects of $\mathrm{Hg}$ exposure are more serious in the developing central nervous system of children than in adults [22]. 
Comparative large studies of general populations of the Amazon have previously showed higher median $\mathrm{HHg}$ values [3]. In our study women between the ages of 16 and 49 years (childbearing females) have median $\mathrm{HHg}$ ranging from 2.4 to $5.3 \mathrm{ppm}$, depending on subsistence living conditions. Comparing these results with an exposure of $1 \mu \mathrm{g} / \mathrm{g}$ in hair for female of childbearing age in the Borum et al. [23], our results are substantially high in the remote area of Resex Cuniã. However, no peak exposures from freshwater fish species with high $\mathrm{Hg}$ concentrations were observed in this study.

In the present study, few hair samples (1.2\%) reached values below $1 \mathrm{ppm}$ in the Cuniã subsistence community, while the other areas showed circa 13\% (Areas 2 and 3), or 18 to $20 \%$ (respectively for Areas 4 and 1). From a practical standpoint, $\mathrm{Hg}$ exposure ( $\mathrm{HHg}$ ) in Amazonian women and children is exclusively from eating fish; other forms of organic mercury (ethylmercury) do exist for young children that are immunized with thimerosal-containing vaccines [24]. However, it is worth noting that the small amounts of ethylmercury in vaccines are not sufficient to be differentiated in hair of children that have been vaccinated for more than three months [25].

Also, for susceptible subgroups (women of pregnant age and young children) Andean Amazon women showed a range of median values (3.3 to $5.5 \mathrm{ppm}$ ) that were comparable to ours [5]. However, in French Guyana, maternal HHg ranged from 2.8 to 12.7 [26]. For women in different parts of the Brazilian Amazon, almost all studies conducted in the Basins of the Negro river [27,28] and the in Tapajós River Basin [29-38] showed higher HHg concentrations than in our current study; an exception was found in women of Alta Floresta [39]. Previous studies in the Madeira river have also shown higher median values than the present study [27,40-42].

There is general agreement that environmental $\mathrm{MeHg}$ exposure during pregnancy poses a significant risk to children's neurodevelopment [43]. The threshold of maternal HHg concentration that may cause adverse effects to the fetus is in the order of 10-20 ppm [44]. However, the potential sub-clinical health effects associated with this variation of exposure in riverine Amazon population are unclear.

The fish species consumed by subsistence Amazonian riverines depend on the catch, which varies with location and season. Although predatory species carry the highest concentrations of $\mathrm{Hg}$, the predominantly available taxa in the riverines' daily diet have much lower $\mathrm{Hg}$ concentrations [10]. In the present study, out of the 106 taxa sampled from the Madeira river, the median $\mathrm{Hg}$ concentrations in $17.7 \%$ exceeded the $0.5 \mu \mathrm{g} / \mathrm{g}$ WHO/FAO limit [45].

Innumerable studies have taken a simplistic approach, classifying fish as piscivorous/carnivorous to represent species at the top of the food chain. This is usually done in studies with a restricted number of taxa or reduced number of samples [9]. In the current study fish were classified more rigorously and the large sampling $(\mathrm{N}=1,615)$ allowed an appraisal of fish availability for the studied areas. Additionally, this rigorous classification as a function of fish feeding behavior revealed patterns of variability in $\mathrm{Hg}$ concentrations. High $\mathrm{Hg}$ levels in piscivorous and carnivorous species are also accompanied by great variability, and together constitute only $30 \%$ of the catch (Figure 4), whereas fish with much lower median $\mathrm{Hg}$ concentrations (omnivorous and detritivorous) make up 53\% of the catch. Therefore, depending on the frequency of consumption (which is a function of availability for subsistence riverines), risk analysis should take such facts in consideration.

Nutrition education and changes in type of fish have been tried for riverines of the Eastern Amazon [46]. However, changes in lifestyle may not translate into the perception of a better 
quality of life [47] and may be disruptive for their strategies of food security, with a possible compromise of nutritional status. Our ongoing studies with this population aim to analyze collected data addressing different biomarkers of nutritional status and health problems associated with a fish-based diet, principally $\mathrm{MeHg}$ exposure and specific outcomes, i.e., pinpointing which benefits and health risks can be evaluated [48]. These studies will clarify what is needed if dietary interventions are to be recommended or implemented.

One of the strength of this study is the large sample size of the population and the high acceptance of the invited communities to participate in this study $(>80 \%)$. This representation was crucial to assess $\mathrm{Hg}$ concentrations in human hair and in fish consumed by riverine communities before the impoundment of reservoir. Our findings are particularly important because they show the current $\mathrm{Hg}$ exposure scenario and how some communities, special the ones more isolated from the urban center, depend on the fish as a source of protein. Therefore, some changes in lifestyle (especially in the riverine communities to be resettled) most probably will reflect in differences in mercury exposure $(\mathrm{HHg})$ between groups. However, personal health consequences are still being evaluated. The weakness is that we cannot yet interpret the health impact of the changes in lifestyle, regarding the benefits of fish in the traditional diet.

\section{Conclusions}

This study does not show up to now any impact of the hydroelectric power plant. It was carried out before the reservoir flooding. Currently available fish in the Madeira river show a wide variability in $\mathrm{Hg}$ concentrations within historical reported values, also regarding the trophic level. Despite cultural similarities, riparians showed $\mathrm{HHg}$ distribution patterns that reflect changes in fish-eating habits driven by subsistence living brought on by socioeconomic changes in the region. However, a marked change in fish-eating habits probably will be verified in the resettled communities closest to the urban area of Porto Velho in few years.

\section{Acknowledgments}

This study was supported by INOVA-ENSP Program2010-2012, CNPq/MCT Universal project $\mathrm{N}^{\text {o }}$ Processo478085/2010-9, under the scope of Hydrobiogeochemistry Monitoring Program from Santo Antônio Energy. We greatly appreciate the riverine communities for their participation. We also thank the students and staff of the Laboratory of Ichthyofauna and Fisheries of University of Rondônia. We are grateful to the staff of the Municipality Health and Education Secretariat, especially teachers and heads of the schools in the surveyed area. We also thank the nurses Nubia Gomes, Andreia Vasconcelos and Janaina Mara for field work, Gabriela Protazio da Silva for the $\mathrm{Hg}$ analysis and Claudio Kleber Juiz de Souza for the map and the work field.

\section{Author Contributions}

Sandra S. Hacon: Coordination of Human Health Fiocruz Program (INOVA ENSP), project planning, organization and participation of all field work that included assessment of human beings, preparation and writing the manuscript. Marlon F. Fonseca: Project planning, participation of 
field work, statistical analysis and writing the manuscript. José G. Dórea: Preparation and writing the manuscript. Dennys S. Mourão: Participation of field work, preparation of the tables and figures. Beatriz A. Oliveira: Participation of field work and preparation and the application of the questionnaires. Claudia M. V. Ruiz: Samples preparation and participation of chemical analysis for determination of mercury concentration in biological samples. Rodrigo A. Gonçalves; Chemical analysis of mercury concentration in biological samples. Carolina F. Mariani: Revision of manuscript. Wanderley R. Bastos: Coordination of the Project with focus on environmental aspects, including chemical analysis for determination of mercury concentration in biological samples

\section{Conflicts of Interest}

The authors declare no conflict of interest.

\section{References}

1. Dórea, J.G. Cassava cyanogens and fish mercury are high but safely consumed in the diet of native Amazonians. Ecotoxicol. Environ. Safety 2004, 57, 248-256.

2. Hacon, S.; Barrocas, P.R.G.; Vasconcellos, A.C.S.D.; Barcellos, C.; Wasserman, J.C.; Campos, R.C.; Ribeiro, C.; Azevedo-Carloni, F.B. An overview of mercury contamination research in the Amazon basin with an emphasis on Brazil. Cadernos de Saúde Pública 2008, 24, 1479-1492.

3. Barbieri, F.; Gardon, J. Hair mercury levels in Amazonian populations: Spatial distribution and trends. Int. J. Health Geogr. 2009, 8, doi:10.1186/1476-072X-8-71.

4. Alves, M.F.A.; Fraiji, N.A.; Barbosa, A.C.; de Lima, D.S.N.; Souza, J.R.; Dórea, J.G.; Cordeiro, G.W.O. Fish consumption, mercury exposure and serum antinuclear antibody in Amazonians. Int. J. Environ. Health Res. 2006, 16, 255-262.

5. Monrroy, S.X.; Lopez, R.W.; Roulet, M.; Benefice, E. Lifestyle and mercury contamination of amerindian populations along the beni river (lowland Bolivia). J. Environ. Health 2008, 71, 44-50.

6. Fearnside, P.M.; Laurance, W.F.; Cochrane, M.A.; Bergen, S.; Sampaio, P.D.; Barber, C.; D’Angelo, S.; Fernandes, T. O futuro da amazônia: Modelos para prever as conseqüências da infraestrutura futura nos planos plurianuais. NCN-Novos Cadernos NAEA 2012, 15, 25-52.

7. Fearnside, P.M. Brazil's samuel dam: Lessons for hydroelectric development policy and the environment in Amazonia. Environ. Manage. 2005, 35, 1-19.

8. Marques, R.C.; Dórea, J.G.; McManus, C.; Leão, R.S.; Brandão, K.G.; Marques, R.C.; Vieira, I.H.I.; Guimarães, J.-R.D.; Malm, O. Hydroelectric reservoir inundation (Rio Madeira basin, Amazon) and changes in traditional lifestyle: Impact on growth and neurodevelopment of pre-school children. Public Health Nutr. 2011, 14, 661-669.

9. Barbosa, A.C.; Souza, J.D.; Dórea, J.G.; Jardim, W.F.; Fadini, P.S. Mercury biomagnification in a tropical black water, Rio Negro, Brazil. Arch. Environ. Contam. Toxicol. 2003, 45, 235-246.

10. Oliveira, R.C.; Dórea, J.G.; Bernardi, J.V.E.; Bastos, W.R.; Almeida, R.; Manzatto, Â.G. Fish consumption by traditional subsistence villagers of the Rio Madeira (Amazon): Impact on hair mercury. Ann. Hum. Biol. 2010, 37, 629-642.

11. Latrubesse, E.M.; Stevaux, J.C.; Sinha, R. Tropical rivers. Geomorphology 2005, 70, 187-206. 
12. Bastos, W.R.; Rebelo, M.D.F.; Fonseca, M.D.F.; Almeida, R.D.; Malm, O. A description of mercury in fishes from the Madeira river basin, Amazon, Brazil. Acta Amazônica 2008, 38, 431-438.

13. Bastos, W.R.; Malm, O.; Pfeiffer, W.C.; Cleary, D. Establishment and analytical quality control of laboratories for $\mathrm{Hg}$ determination in biological and geological samples in the Amazon, Brazil. Ciênc. Cult. (Säo Paulo) 1998, 50, 255-260.

14. Dos Santos, G.M.; Jegu, M.; Merona, B.D. Catálogo de Peixes Comerciais do Baixo Rio Tocantins. In Projeto Tucuruí; INPA: Rio de Janeiro, Brazil, 1984.

15. Nelson, H.D. Menopause. The Lancet 2008, 371, 760-770.

16. Kjellstrom, T.S. Physical and Mental Development of Children with Prenatal Exposure to Mercury from Fish: Stage 1, Preliminary Tests at Age 4; Statens Naturvardsverk: Stockholm, Sweden, 1986.

17. Kjellström, T.; Kennedy, P.; Wallis, S.; Stewart, A.; Friberg, L.; Lind, B.; Wutherspoon, T.; Mantell, C. Physical and Mental Development of Children with Prenatal Exposure to Mercury from Fish. Stage 2. Interviews and Psychological Tests at Age 6; Statens Naturvardsverk: Stockholm, Sweden, 1989.

18. Methylmercury, W. Environmental Health Criteria 101; WHO: Geneva, Swizerland, 1990; pp. 1-144.

19. Cerdeira, R.G.P.; Ruffino, M.L.; Isaac, V.J. Consumo de pescado e outros alimentos pela população ribeirinha do lago grande de monte alegre, pa. Brasil. Acta Amazônica 1997, 27, 213-228.

20. Cowx, I.; O’Grady, K.; Batista, V.; Inhamuns, A.; Freitas, C.; Freire-Brasil, D. Characterization of the fishery in river communities in the low-solimões/high-amazon region. Fisheries Manag. Ecol. 1998, 5, 419-435.

21. Boischio, A.; Henshel, D.S. Risk assessment of mercury exposure through fish consumption by the riverside people in the Madeira basin, Amazon, 1991. Neurotoxicology 1996, 17, 169-175.

22. Guidance for Identifying Populations at Risk from Mercury Exposure; WHO: Geneva, Switzerland, 2008.

23. Borum, D.; Manibusan, M.K.; Schoeny, R.; Winchester, E.L. Water Quality Criterion for the Protection of Human Health: Methylmercury; EPA: Washington, DC, USA, 2001.

24. Marques, R.C.; Dórea, J.G.; Bernardi, J.V.E.; Bastos, W.R.; Malm, O. Prenatal and postnatal mercury exposure, breastfeeding and neurodevelopment during the first 5 years. Cogn. Behav. Neurol. 2009, $22,134-141$.

25. Dórea, J.G.; Bezerra, V.L.V.A.; Fajon, V.; Horvat, M. Speciation of methyl- and ethyl-mercury in hair of breastfed infants acutely exposed to thimerosal-containing vaccines. Clin. Chim. Acta 2011, 412, 1563-1566.

26. Cordier, S.; Garel, M.; Mandereau, L.; Morcel, H.; Doineau, P.; Gosme-Seguret, S.; Josse, D.; White, R.; Amiel-Tison, C. Neurodevelopmental investigations among methylmercury-exposed children in french Guiana. Environ. Res. 2002, 89, 1-11.

27. Barbosa, A.C.; Dórea, J.G. Indices of mercury contamination during breast feeding in the Amazon basin. Environ. Toxicol. Pharmacol. 1998, 6, 71-79.

28. Barbosa, A.C.; Jardim, W.; Dórea, J.G.; Fosberg, B.; Souza, J. Hair mercury speciation as a function of gender, age, and body mass index in inhabitants of the Negro river basin, Amazon, Brazil. Arch. Environ. Contam. Toxicol. 2001, 40, 439-444. 
29. Amorim, M.; Mergler, D.; Bahia, M.; Dubeau, H.; Miranda, D.; Lebel, J.; Burbano, R.; Lucotte, M. Cytogenetic damage related to low levels of methyl mercury contamination in the Brazilian Amazon. An. Acad. Bras. Ciênc. 2000, 72, 497-507.

30. Dolbec, J.; Mergler, D.; Passos, C.J.S.; de Morais, S.S.; Lebel, J. Methylmercury exposure affects motor performance of a riverine population of the Tapajós river, Brazilian Amazon. Int. Arch. Occup. Envir. Health 2000, 73, 195-203.

31. Dolbec, J.; Mergler, D.; Larribe, F.; Roulet, M.; Lebel, J.; Lucotte, M. Sequential analysis of hair mercury levels in relation to fish diet of an Amazonian population, Brazil. Sci. Total Envir. 2001, 271, 87-97.

32. Lebel, J.; Roulet, M.; Mergler, D.; Lucotte, M.; Larribe, F. Fish diet and mercury exposure in a riparian Amazonian population. Water Air Soil Pollut. 1997, 97, 31-44.

33. Lebel, J.; Mergler, D.; Branches, F.; Lucotte, M.; Amorim, M.; Larribe, F.; Dolbec, J. Neurotoxic effects of low-level methylmercury contamination in the Amazonian basin. Environ. Res. 1998, 79, 20-32.

34. Grandjean, P.; White, R.; Nielsen, A.; Cleary, D.; de Oliveira Santos, E. Methylmercury neurotoxicity in Amazonian children downstream from gold mining. Environ. Health Perspect. 1999, 107, 587-591.

35. Barbosa, A.; Garcia, A.; Souza, J. Mercury contamination in hair of riverine populations of apiacás reserve in the Brazilian Amazon. Water Air Soil Pollut. 1997, 97, 1-8.

36. Passos, C.J.; Mergler, D.; Gaspar, E.; Morais, S.; Lucotte, M.; Larribe, F.; Davidson, R.; Grosbois, S.D. Eating tropical fruit reduces mercury exposure from fish consumption in the Brazilian Amazon. Environ. Res. 2003, 93, 123-130.

37. Pinheiro, M.C.N.; Crespo-López, M.E.; Vieira, J.L.F.; Oikawa, T.; Guimarães, G.A.; Araújo, C.C.; Amoras, W.W.; Ribeiro, D.R.; Herculano, A.M.; do Nascimento, J.L.M.; et al. Mercury pollution and childhood in Amazon riverside villages. Environ. Int. 2007, 33, 56-61.

38. Pinheiro, M.C.N.; Müller, R.C.S.; Sarkis, J.E.; Vieira, J.L.F.; Oikawa, T.; Gomes, M.S.V.; Guimarães, G.A.; do Nascimento, J.L.M.; Silveira, L.C.L. Mercury and selenium concentrations in hair samples of women in fertile age from Amazon riverside communities. Sci. Total Envir. 2005, 349, 284-288.

39. Hacon, S.; Yokoo, E.; Valente, J.; Campos, R.C.; da Silva, V.A.; de Menezes, A.C.C.; de Moraes, L.P.; Ignotti, E. Exposure to mercury in pregnant women from alta floresta-Amazon basin, Brazil. Environ. Res. 2000, 84, 204-210.

40. Boischio, A.; Henshel, D. Human biomonitoring to optimize fish consumption advice: Reducing uncertainty when evaluating benefits and risks. Environ. Res. 2000, 84, 108-126.

41. Bastos, W.R.; Gomes, J.P.O.; Oliveira, R.C.; Almeida, R.; Nascimento, E.L.; Bernardi, J.V.E.; de Lacerda, L.D.; da Silveira, E.G.; Pfeiffer, W.C. Mercury in the environment and riverside population in the Madeira river basin, Amazon, Brazil. Sci. Total Envir. 2006, 368, 344-351.

42. Marques, R.C.; Garrofe Dórea, J.; Bastos, W.R.; de Freitas Rebelo, M.; de Freitas Fonseca, M.; Malm, O. Maternal mercury exposure and neuro-motor development in breastfed infants from Porto Velho (Amazon), Brazil. Int. J. Hyg. Environ. Health 2007, 210, 51-60.

43. Trasande, L.; Landrigan, P.J.; Schechter, C. Public health and economic consequences of methyl mercury toxicity to the developing brain. Environ. Health Perspect. 2005, 113, 590-596. 
44. Clarkson, T.W. Environmental contaminants in the food chain. Amer. J. Clin. Nutr. 1995, 61, S682-S686.

45. Evaluation of Certain Food Additives and Contaminants: Sixty-eighth Report of the Joint FAO/Who Expert Committee on Food Additives (Geneva from 19 to 28 June 2007); WHO: Geneva, Swizerland, 2007; Vol. 947.

46. Fillion, M.; Philibert, A.; Mertens, F.; Lemire, M.; Passos, C.; Frenette, B.; Guimarães, J.; Mergler, D. Neurotoxic sequelae of mercury exposure: An intervention and follow-up study in the Brazilian Amazon. Ecohealth 2011, 8, 210-222.

47. Fillion, M.; Passos, C.; Lemire, M.; Fournier, B.; Mertens, F.; Guimarães, J.; Mergler, D. Quality of life and health perceptions among fish-eating communities of the Brazilian Amazon: An ecosystem approach to well-being. Ecohealth 2009, 6, 121-134.

48. Fonseca, M.D.F.; de Souza Hacon, S.; Grandjean, P.; Choi, A.L.; Bastos, W.R. Iron status as a covariate in methylmercury-associated neurotoxicity risk. Chemosphere 2014, 100, 89-96.

(C) 2014 by the authors; licensee MDPI, Basel, Switzerland. This article is an open access article distributed under the terms and conditions of the Creative Commons Attribution license (http://creativecommons.org/licenses/by/3.0/). 